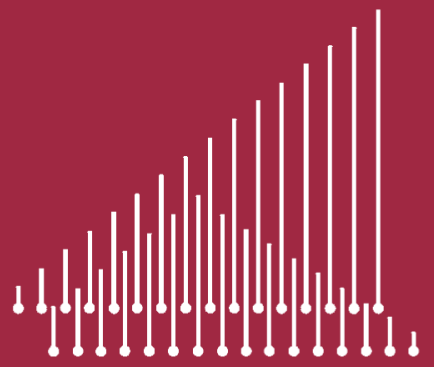

National Institute Economic Review Journal of the National Institute of Economic and Social Research

No. 23I February 2015

\title{
ECONOMIC PROSPECTS
}

Commentary: The macroeconomic implications of the parties' fiscal plans by Simon Kirby

The world economy edited by Graham Hacche

Oil prices and economic activity by Simon Kirby and Jack Meaning

The UK economy edited by Simon Kirby

As good as it gets? The UK labour market in recession and recovery by David G. Blanchflower

THE ECONOMIC RECORD OF THE COALITION GOVERNMENT Introduction

by Jonathan Portes

The macroeconomic record of the coalition government by Simon Wren-Lewis

UK economic growth since 2010: is it as bad as it seems? by Nicholas Crafts

Why should we care about productivity?

by Vicky Pryce

Education policy by Rebecca Allen

Retrenchment, reform, continuity: welfare under the coalition by Declan Gaffney 


\section{National Institute Economic Review No. 23 I February 2015}

Page

FORECAST OVERVIEW

COMMENTARY

The macroeconomic implications of the parties'

fiscal plans

Simon Kirby

THE WORLD ECONOMY

World overview

$\mathrm{FI} 2$

Prospects for individual economies

FI8

Appendix A: Key forecast assumptions

F29

Appendix B: Forecast detail

F36

Graham Hacche, with Oriol Carreras, Simon Kirby, lana Liadze, Jack Meaning, Kanya Paramaguru, Rebecca Piggott,

Miguel Sánchez-Martínez and James Warren

Oil prices and economic activity

Simon Kirby and Jack Meaning

THE UK ECONOMY

Prospects for the UK economy

Simon Kirby, with Oriol Carreras, Jack Meaning,

Rebecca Piggott and James Warren

As good as it gets? The UK labour market in recession and recovery

F76

David G. Blanchflower

RESEARCH ARTICLES

THE ECONOMIC RECORD OF THE COALITION GOVERNMENT Introduction

Jonathan Portes

The macroeconomic record of the coalition government

Simon Wren-Lewis

UK economic growth since 2010 : is it as bad as it seems?

Nicholas Crafts

Why should we care about productivity?

Vicky Pryce

Education policy

Rebecca Allen

Retrenchment, reform, continuity: welfare under the coalition 